\title{
FINANCE AND GROWTH: \\ HOUSEHOLD SAVINGS, PUBLIC INVESTMENT, AND PUBLIC HEALTH IN \\ LATE NINETEENTH-CENTURY NEW JERSEY
}

\author{
Howard Bodenhorn \\ Working Paper 23430 \\ http://www.nber.org/papers/w23430
NATIONAL BUREAU OF ECONOMIC RESEARCH
1050 Massachusetts Avenue
Cambridge, MA 02138

May 2017

I thank Brian Beach, Michael Bordo, Ray Cohn, Gail Triner, Eugene White and seminar participants at Rutgers for valuable comments. Richard Sutch deserves special mention; he has been generous in providing comments and sharing his understanding of late nineteenth-century household savings behaviors. Veronia Aoki Santarosa, Denica Karadzhova, Dimitar Marmarov, and Justus Staisiunas provided exceptional research assistance. The views expressed herein are those of the author and do not necessarily reflect the views of the National Bureau of Economic Research.

NBER working papers are circulated for discussion and comment purposes. They have not been peer-reviewed or been subject to the review by the NBER Board of Directors that accompanies official NBER publications.

(C) 2017 by Howard Bodenhorn. All rights reserved. Short sections of text, not to exceed two paragraphs, may be quoted without explicit permission provided that full credit, including () notice, is given to the source. 
Finance and Growth: Household Savings, Public Investment, and Public Health in Late Nineteenth-Century New Jersey Howard Bodenhorn

NBER Working Paper No. 23430

May 2017

JEL No. I15,N31

\begin{abstract}
Saving is essential to the health of economies because it provides the wherewithal for investment. In the late nineteenth century, saving was also essential to the health of urban working-class households. This study brings together information from surveys of household spending and saving, reports of savings banks and insurance companies, water and sewer authorities, and health commissioners to illuminate the connections between household savings and health improvements. Contemporary financial institutions positively influenced economic growth by allocating capital to highly productive employments, including public infrastructure. Specifically, investments in waterworks contributed to the long-run decline in typhoid infection, which improved worker health and productivity.
\end{abstract}

Howard Bodenhorn

John E. Walker Department of Economics

College of Business

201-B Sirrine Hall

Clemson University

Clemson, SC 29634

and NBER

bodenhorn@gmail.com 
"Where people who are equally industrious, intelligent and capable are competing, the advantage in the long run will be on the side of the most thrifty." (Schoenfeld 1925, p.1)

\section{Introduction}

Understanding individual thrift is central to understanding long-run economic development because saving is the source of capital, a principal factor of production and one that influences labor productivity and growth. "It is because of this relation between saving and productive capital," writes Modigliani (1986, p. 297), "that thrift has traditionally been regarded as a virtuous, socially beneficial act." This was certainly the view of early nineteenth-century policy makers who considered individual thrift indispensible not just for long-term development but for personal and civic well-being (Wadwhani 2002). In the late nineteenth century, individual thrift and personal well-being were more closely connected than hitherto understood.

This study brings together information from a wide variety of sources to trace out the connection between working-class saving and economic growth illustrated in Figure 1. Using information reported in five surveys of late nineteenthcentury New Jersey industrial workers, this study first documents that about one-half of working-class households saved in a given year and that they saved as much as $12 \%$ of their annual incomes. As might be expected in an economy without a strong safety net, households at all income percentiles engaged in net saving, though households dissaved regularly as well, a result consistent with other studies of contemporary working-class households (Alter et al 1994; Wadhwani 2002; Sutch 2011). 
Figure 1: Financial flows, intermediation, and long-run growth

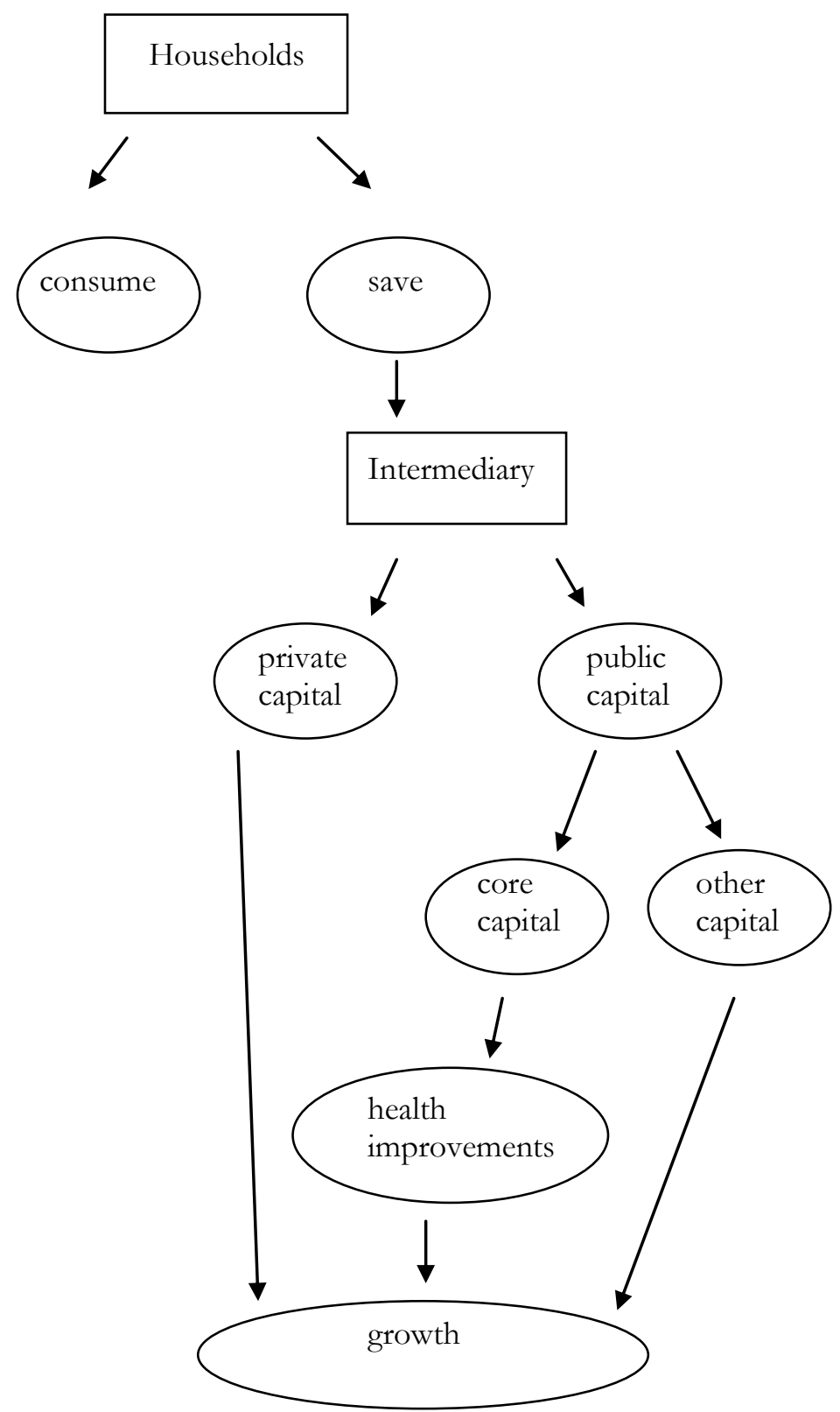


After documenting household saving behaviors, the paper explores how households saved and with which intermediaries. It appears that working-class households were relatively sophisticated savers who spread their savings across available saving vehicles that, in combination, offered alternative combinations of liquidity, risk, and return. Mutual savings banks offered liquidity and low risk (Payne and Davis 1956; Olmstead 1976); industrial life insurance companies guaranteed households against the unexpected death of householders (North 1979); building and loan associations opened the door to home ownership to urban, working-class households (Bodfish 1931; Snowden 2003); and fraternal beneficial societies offered health and life insurance (Beito 2000; Murray 2007). One-half or more of these institutions' portfolios were invested in the era's high return, high productivity sectors such as residential housing and railroads, but one-third or more was invested in public-sector capital.

In the 1880 s, much of that public-sector investment was directed into what Aschaeur (1989) labels core capital, mostly water and sewer infrastructure. In the last three decades of the nineteenth-century, 94 of New Jersey's municipalities invested in new or upgraded waterworks, at an average cost of more than $\$ 400,000$ (or about $\$ 10$ million in 2016 dollars, Williamson 2017). About 75\% of the cost was financed with 10- to 30-year municipal bonds that found their way into the portfolios of the state's mutual savings banks and life insurance companies. New Jersey's workingclass savers, therefore, indirectly invested in their own community's water infrastructure.

New and additional municipal investments in local waterworks encouraged the use of publicly supplied water. Once the water systems tapped into relatively pure, water sources, typhoid mortality rates declined markedly. In Newark typhoid mortality declined from an average of 62.2 deaths per 100,000 to 22.2; Jersey City experienced an even more marked decline from 73.6 to 25.1 per 100,000 once its waterworks tapped into a pure water supply. The available evidence from New Jersey does not afford a direct test of the hypothesis, but a number of studies of other places demonstrate a connection between decreased typhoid mortality rates and later-life labor productivity and economic growth (Costa 2000; Ferrie and Troesken 
2008; Case and Paxson 2009; Beach et al 2016). Thus, it seems fair to conclude that New Jersey's late nineteenth-century working-class households financed, at least in part, their own health and productivity gains. One contribution of this paper is that it documents this important channel between finance and growth that the now extensive literature has not previously studied (Levine 1997; Bodenhorn 2016).

\section{Savings mobilization, finance, and development}

Financial institutions allocate and invest society's savings, so financial performance has important effects on capital allocation, industrial growth, technological advancement, and economic development (Berger et al 2004). The now extensive literature exploring the connection between finance and long-run growth argues that financial institutions encourage growth and development because they ameliorate transaction and information costs and facilitate the allocation of resources across space and time in the face of risk and uncertainty (Merton and Bodie 1995). Financial institutions provide these risk-management services by performing five critical functions: they mobilize savings; allocate savings to alternative investment projects; monitor and exert control over borrowers; reduce savers' risk by holding a diversified portfolio of investments; and facilitate trade through the provision of exchange media (Levine 1997). Economists argue that better financial institutions - that is, institutions that better identify creditworthy borrowers, better mobilize savings, better pool risk, monitor better, and better facilitate transactions - accelerate economic growth (Levine 1998). Scores of modern finance-growth studies acknowledge the importance of all five functions, but most follow King and Levine (1993) in their focus on private credit creation and allocation mechanisms, particularly the efficiency with which they allocate capital, encourage entrepreneurial enterprise, and increase total factor productivity growth.

The literature that considers the finance-growth connection in historical contexts follows the modern approach in its focus on the allocation mechanism mediated through the sector's provision of the media of exchange (Rockoff 1975; Lamoreaux 1994; Bodenhorn 2000, 2016; Rousseau and Sylla 2005). It is surprising how little attention has been afforded the mobilization mechanism given the financial sector's ability to mobilize, evidence of which is the relatively high saving 
and capital formation rates exhibited by nineteenth-century Americans (Gallman 1986). Saving mobilization is, therefore, very nearly the "forgotten half" of finance (Adams and Vogel 1986). Financial institutions not only engage in the four lendingrelated functions; they provide deposit facilities and other repositories for household saving.

Savings mobilization involves creating liquid, small-denomination financial claims on large, indivisible, high-return investments. One hallmark of modern industrial economies is the exploitation of economics of scale and scope, which depends on the agglomeration of capital from dispersed, anonymous, small-scale saver-investors. A second hallmark is the ability of financial intermediaries to attract working- and middle-class savers, even if indirectly, into the market for securities issued by enterprises large enough to exploit available economies. Intermediaries succeed in this to the extent that they can offer secondary or derivative securities whether bank deposits, life insurance policies, mutual funds, and so forth - that offer liquidity, maturity, and safety characteristics for a given real return that households find more attractive than primary securities. One of the principal functions is for intermediaries to transfer savings across time and space because any geographical or temporal (maturity) correspondence between savings and investment is purely coincidental (Wilhelm 2001). One benefit of intermediation then is that intermediated savings moves toward investment projects that lay outside the reach or experience of savers, who tend to be most comfortable with investments they can see and touch and comprehend (Payne and Davis 1956). ${ }^{1}$

The nineteenth century US witnessed the emergence and expansion of several specialized intermediaries designed to tap into pools of working- and middleclass savings - to pull it from under the proverbial mattress - and invest in a wide variety of private and public projects. Mutual savings banks, which first appeared in the 1810s in the nation's commercial centers, catered to the working classes and offered them a safe repository for modest household savings. By century's end, the northeastern US had more than 650 mutual savings banks with nearly 5.4 million accounts holding deposits worth $\$ 2.1$ billion, or about $1 \%$ of gross domestic

1 Even Warren Buffett, the CEO of Bershire-Hathaway and the so-called "Oracle of Omaha," follows an investment strategy that prefers less complex business models and "buying what you know." 
product. Building and loan associations, the precursor of the twentieth century's savings and loan associations, afforded working-class households opportunities to own their own homes. Life insurance companies such as New Jersey's Prudential Insurance Company offered small policies for modest premiums paid weekly. And households could insure themselves against bouts of unemployment and sickness through small, regular payments to beneficial societies. It should be no surprise that the working classes saved because without regular saving small misfortunes could become dire emergencies (Adams and Vogel 1986).

\section{Late nineteenth-century urban working-class household saving behaviors}

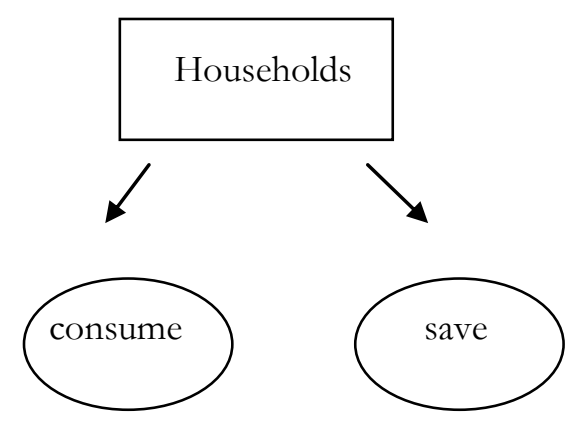

Following the flow chart in Figure 1, the first step is to determine whether New Jersey's industrial workers saved and, if so, how much. The data used to answer this and subsequent questions were collected, compiled, and reported by various state bureaus and regulatory bodies. The principal source of evidence on household saving behaviors is five reports issued by the New Jersey Bureau of Statistics of Labor and Industries (hereafter, NJBSLI) between 1883 and 1888. Modeled after the Massachusetts bureau headed by Carroll D. Wright, the NJBSLI conducted the same type of annual surveys of working-class men and women. The details of the surveys change from year to year, but certain questions appeared in each survey: the city or town in which the household head worked; the broad industry in which he or she worked (i.e., glass, iron, construction, etc.); a reasonably precise job title (i.e., green bottle glass blower, puddler, plasterer, etc.); the number of hours worked per day; typical wages by day, week or month, depending on how often the individual was paid; the number of working days the individual was not employed due to sickness, 
an inability to find work (which usually implied scheduled seasonal factory shutdowns or slowdowns), and other reasons; the number of individuals in the household; the worker's annual income from his or her job; any additional income aggregated up to an annual figure provided by other household members employed outside the home; the household's total annual expenses, sometimes broken down into categories such as rent, food, clothing, and other expenses; and a yes-no question indicating whether the household had accumulated any savings in the past year or incurred any new debt. Other questions were included in some but not all years. Despite the detail of the surveys, the bureau did not ask what now seem to be obvious questions, such as the age of the surveyed worker or other household members, marital status, education, or job experience.

Despite the lack of information on age and other characteristics, the surveys contain a wealth of information on the nature of working-class household saving behaviors that have been long neglected (Carter et al 1991), and shed light on historical household choices. The first issue is whether late nineteenth-century households had the wherewithal to save and, if so, did they. Table 1, which compiles data from the five worker surveys conducted between 1883 and 1888, provides summary statistics. Household heads' earnings averaged between $\$ 550$ and $\$ 650$, with annual fluctuations due in part to the changing industrial composition of survey respondents. Reported earnings are consistent with estimates of GDP per worker derived from available national income account: $\$ 686.30$ in 1880 and $\$ 617.57$ in 1890 (Carter et al 2006, Series Ca9-19, Ba1-10, Ba40-49). About one-third of survey respondents reported one or more additional individuals, mostly youth, residing in the household and working for wages. On average, they contributed between $\$ 50$ and $\$ 100$ per year to total household income. Total household income at the respondents' households then averaged between $\$ 600$ and $\$ 700$ per year. Median household incomes are between $\$ 40$ and $\$ 60$ less than mean incomes. 


\begin{tabular}{|c|c|c|c|c|c|c|}
\hline \multicolumn{7}{|c|}{ Table 1} \\
\hline \multicolumn{7}{|c|}{ Statistics of income, expenditures, employment and savings } \\
\hline & \multicolumn{5}{|c|}{$\underline{\text { Unadjusted }}$} & \multirow{2}{*}{$\frac{\text { Adjusted }}{\text { all years }}$} \\
\hline & 1883 & 1884 & 1885 & 1886 & 1888 & \\
\hline \multirow[t]{2}{*}{ Household head income } & 605.44 & 598.51 & 542.11 & 596.22 & 606.75 & \\
\hline & [279.53] & [243.42] & [249.86] & [258.37] & [239.12] & \\
\hline \multirow[t]{2}{*}{ Earnings of others } & 100.33 & 49.06 & 67.9 & 107.11 & 96.96 & \\
\hline & [164.21] & [111.62] & [134.84] & {$[171.70]$} & [171.46] & \\
\hline \multirow[t]{2}{*}{ Household income } & 705.77 & 647.57 & 610.02 & 703.33 & 703.71 & 746.41 \\
\hline & [306.06] & {$[260.86]$} & [264.99] & {$[295.67]$} & {$[273.71]$} & [282.34] \\
\hline Median household income & 650 & 600 & 550 & 653 & 667 & 700 \\
\hline \multirow[t]{2}{*}{ Total expenditures } & 628.11 & 565.07 & 556.09 & 637.21 & 604.25 & 647.87 \\
\hline & [223.21] & [208.47] & [189.00] & {$[215.26]$} & [194.37] & [201.04] \\
\hline \multirow[t]{2}{*}{ Saving rate } & 0.07 & 0.10 & 0.04 & 0.05 & 0.11 & 0.12 \\
\hline & {$[0.16]$} & {$[0.17]$} & {$[0.18]$} & {$[0.17]$} & {$[0.16]$} & {$[0.16]$} \\
\hline \multicolumn{7}{|c|}{ Responses to survey questions concerning household saving } \\
\hline \multirow[t]{2}{*}{ Saving in previous years } & 0.479 & 0.49 & 0.56 & & & 0.53 \\
\hline & {$[0.500]$} & {$[0.50]$} & {$[0.50]$} & & & {$[0.50]$} \\
\hline \multirow[t]{2}{*}{ Saving in present year } & 0.39 & 0.43 & 0.42 & & & 0.47 \\
\hline & [0.49] & {$[0.50]$} & [0.49] & & & {$[0.50]$} \\
\hline \multirow[t]{2}{*}{ Gone into debt present year } & 0.43 & 0.78 & 0.73 & & & 0.74 \\
\hline & {$[0.49]$} & {$[0.41]$} & {$[0.45]$} & & & {$[0.44]$} \\
\hline \multicolumn{7}{|c|}{ Industry of employment } \\
\hline Glass & 0.30 & 0.20 & 0.19 & 0.26 & 0.23 & \\
\hline Manufacturing & 0.10 & 0.21 & 0.18 & 0.09 & 0.18 & \\
\hline Textiles & 0.21 & 0.13 & 0.17 & 0.23 & 0.09 & \\
\hline Metals & 0.08 & 0.10 & 0.07 & 0.14 & 0.12 & \\
\hline Construction & 0.06 & 0.05 & 0.08 & 0.05 & 0.10 & \\
\hline Shoes & 0.08 & 0.07 & 0.07 & 0.09 & 0.04 & \\
\hline Transportation & 0.04 & 0.07 & 0.06 & 0.04 & 0.08 & \\
\hline Clothing & 0.07 & 0.07 & 0.06 & 0.01 & 0.05 & \\
\hline Services & 0.01 & 0.03 & 0.05 & 0.03 & 0.07 & \\
\hline Mining & 0.02 & 0.00 & 0.04 & 0.02 & 0.01 & \\
\hline Tobacco & 0.01 & 0.02 & 0.01 & 0.01 & 0.02 & \\
\hline Other industries & 0.02 & 0.03 & 0.03 & 0.03 & 0.02 & \\
\hline Observations & 421 & 1025 & 534 & 316 & 644 & 1676 \\
\hline $\begin{array}{l}\text { Note: adjusted values imput } \\
\text { society dues. Standard devia } \\
\text { Source: New Jersey Bureau }\end{array}$ & $\begin{array}{l}\text { in for re } \\
\text { tistics of }\end{array}$ & $\begin{array}{l}\text { value of o } \\
\text { or and In }\end{array}$ & $\begin{array}{l}\text { er-occupi } \\
\text { tries (188 }\end{array}$ & $\begin{array}{l}\text { housing, } \\
\text { 89). }\end{array}$ & life insu & ce and \\
\hline
\end{tabular}

The surveys also questioned respondents about household expenses for the past year. In some years the survey asked for total household expenditures; in other 
years the survey asked respondents to provide detailed budgets on rent, food, clothing, sundries and other expenditures. In a single year, the surveys asked about expenditures on life and sickness insurance, which represent saving rather than current expenditure. Although it will generate a noisy measure, the data can be used to calculate working-class household saving rates.

An approximate household saving rate is then calculated as the difference between household income and expenditure all divided by household income. ${ }^{2}$ The implied average saving rate for all five years is $8.1 \%$, but ranges between 4 and $10 \%$. If adjustments are made to account for underreported homeownership and treat life insurance payments as savings rather than current expenditures, the five-year average is $11.9 \%{ }^{3}$

The 1883 through 1885 surveys also afford a secondary check on the validity of the estimated saving rates. These three surveys asked simple yes-or-no questions: "Have you accumulated any savings during the past [current] year?" The responses were coded as 0 (no) or 1 (yes). Approximately $40 \%$ reported saving in the past year, and about $50 \%$ reported saving in prior years, both of which point to a culture of working-class saving. The simple correlation coefficient between saving in the current year and the estimated saving rate is 0.62 ( $\mathrm{p}$-value $<0.001)$. Table 2 provides a two-by-two tabulation of the zero-one response to saving in the current year with a

2 While there are subtle differences, most theories of saving define annual saving as net changes in net wealth, which would include changes in cash holdings and durable goods, which supply a flow of future services. Changes in net wealth are approximately the difference between disposable income less expenditures on perishables and current services. Absent information on wealth or information on expenditures on durables and services, the saving rate is measured as the difference between household income less expenditure all divided by household income (e.g., saving rate $=$ (total income total expenditure)/total income). This measure provides a lower bound estimate of the saving rate because some reported expenditures would qualify as saving. The 1886 survey, for example, asked about life insurance payments and sickness society dues (discussed in greater detail in the Section 3), which averaged $\$ 11.10$ per household. If these values are included in "Sundry" expenditures in other years, the calculated saving rate will be below the actual rate. In addition, other households did not report a value for house rent. In a few instances, the survey noted that the respondent owned his or her own house. If we assume all respondents that failed to return a rent value lived in owner-occupied housing, this implies an ownership rate of 58.1\%. The Census Bureau (2017) estimates the home ownership rate in New Jersey at $34.3 \%$ in 1900, so attributing a rental value of home ownership to the savings of households that failed to report rent will overestimate homeownership and, therefore, saving rates. When the owner-occupied and society dues adjustments are made to the reported income and expenditure accounts, the five-year average saving rate increases to $12 \%$, which is consistent with the Alter et al (1994) estimate.

${ }^{3}$ Saving rates for New Jersey workers are about the same as the $10 \%$ to $15 \%$ among account holders at the Philadelphia Savings Fund Society (Alter, Goldin and Rotella 1994), though it is lower than for industrial workers in 1880s Kansas (Sutch 2011). 
zero-one transform of the estimated saving rate in which positive saving equals one and either zero or negative saving is coded as zero. Although a substantial fraction of workers report that they did not save during the current year and exhibit positive value of income less expenditures, $81.5 \%$ of households are on the diagonal, which implies a generally high level of consistency between reported savings and calculated saving rates.

\begin{tabular}{|c|c|c|c|c|}
\hline \multicolumn{5}{|c|}{ Table 2} \\
\hline \multicolumn{5}{|c|}{ New Jersey industrial workers reported versus estimated saving } \\
\hline & & \multicolumn{2}{|c|}{ Estimated savings } & \multirow[b]{2}{*}{ Total } \\
\hline & & Negative or zero & Positive & \\
\hline \multirow{3}{*}{$\frac{\text { Saved in }}{\frac{\text { current }}{\text { year }}}$} & No & 672 & 261 & 933 \\
\hline & Yes & 36 & 635 & 671 \\
\hline & Total & 708 & 896 & 1604 \\
\hline Source: I & LI (188 & & & \\
\hline
\end{tabular}

Figure 2 presents a Brady-Friedman-style (1947) graph of household saving rates plotted against the household's place in the income distribution reported as percentiles. The estimated relationship is calculated using a third-degree polynominal (fourth- and fifth-degree estimates yielded similar shapes). The graph is consistent with three typical features of saving estimates (Deaton 1992). First, about one-third of households report annual income equal to annual expenditure, a feature consistent with consumer impatience. Second, households at all points in the income distribution exhibit positive saving, but saving rates increase in income. And, third, dissaving is common. The saving rates revealed in the graph are consistent with nineteenth-century household saving behaviors consistent with Modigliani's life-cycle (Sutch 2011) and Friedman's permanent-income hypotheses (Bodenhorn 2017). 


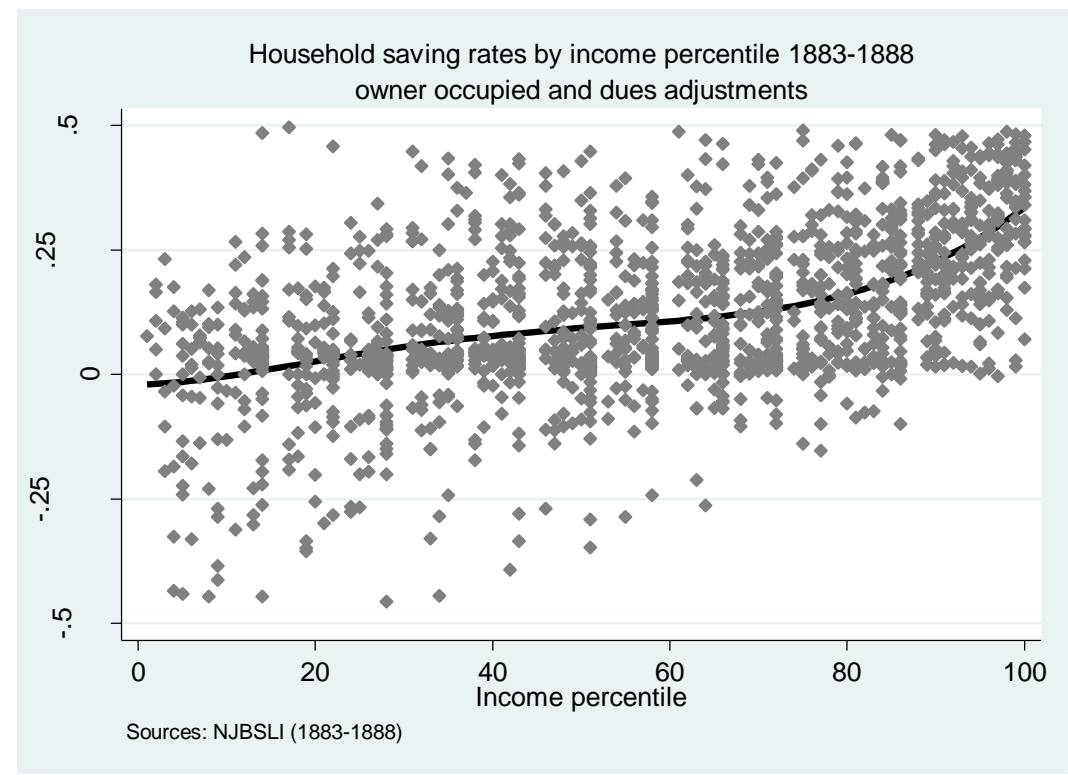

Evidence on late nineteenth-century working-class households reveals that their saving behaviors were largely consistent with modern approaches, but the predictions derived from modern theory are consistent with liquidity constraints or imperfections in capital markets (Browning and Lusardi 1996). The principal capital market imperfection in modern theory is one in which young households prefer to consume more early in life but cannot because capital markets preclude borrowing against future income. Nineteenth-century householders surely faced capital market imperfections in the sense that they found it difficult to smooth consumption by borrowing in youth, repaying loans and saving in middle age, and dissaving in retirement.

Early nineteenth-century households faced a more fundamental market "imperfection," namely the near absence of banks and other organizations that offer services designed to solve the complex dynamic optimization problem inherent to smoothing consumption over a person's expected life. But the fundamental imperfection was less of a constraint later in the century. Over the course of the nineteenth century a handful of institutions emerged - mutual savings banks, building and loan associations, life insurance companies, sickness and other beneficial societies, among others - that helped working-class and middle-class 
households realize something closer to their optimal life-cycle path of consumption and saving.

\section{Institutions and household allocations}

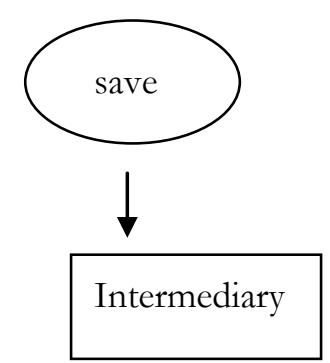

As step three of Figure 1 makes clear, if working households saved, the question arises about how savings were allocated across alternative outlets. By the 1880s households had several alternatives, and they made use of the alternatives in varying proportions based on the reasons for saving and preferences for liquidity, maturity, and divisibility. One report from the NJBSLI (1888) sheds light on the extent to which working-class households made use of the four principal savings vehicles available to them. In addition to the questions included in earlier surveys, the 1888 survey inquired into whether the head of the household held an account at a savings bank, a building and loan association, whether he or she had a life insurance policy, or belonged to a beneficial society. The 1888 survey also inquired into the amounts held in savings accounts and the amount of insurance, but the response rate to the last two questions was low. 


\begin{tabular}{|c|c|c|c|c|c|}
\hline \multicolumn{6}{|c|}{ Table 4} \\
\hline \multicolumn{6}{|c|}{ Statistics of household saving and membership } \\
\hline & Mean & Median & & Mean & Median \\
\hline \multirow[t]{2}{*}{ Income } & 709.12 & 667 & Beneficial society & 0.49 & 0 \\
\hline & [278.10] & & & {$[0.50]$} & \\
\hline \multirow[t]{2}{*}{ Saving rate } & 0.12 & 0.07 & Union member & 0.54 & 1 \\
\hline & {$[0.17]$} & & & {$[0.50]$} & \\
\hline \multirow[t]{2}{*}{ Savings bank acct } & 0.16 & 0 & Saving account & 240.23 & 175 \\
\hline & {$[0.37]$} & & & [288.63] & \\
\hline \multirow[t]{2}{*}{ Life insurance } & 0.55 & 1 & Insured value & 701.98 & 300 \\
\hline & {$[0.49]$} & & & [890.10] & \\
\hline \multirow{2}{*}{$\begin{array}{l}\text { Building } \\
\text { association }\end{array}$} & 0.24 & 0 & & & \\
\hline & {$[0.43]$} & & & & \\
\hline \multicolumn{6}{|c|}{$\begin{array}{l}\text { Source: NJBSLI }(1888) \text {. } \\
\text { Notes: } 625 \text { observations, except dollar value of savings accounts }(\mathrm{N}=22) \text { and insured value } \\
(\mathrm{N}=) \text {. }\end{array}$} \\
\hline
\end{tabular}

Table 4 reports mean and median values for selected statistics related to savings, namely, household incomes, saving rates, amounts held in saving and life insurance accounts, and the fraction of households participating in each type of organization. Mean income among the 1888 respondents was $\$ 709$; median income was $\$ 667$. The mean saving rate was $12 \%$; the median rate was $7 \%$ for the subsample of 625 respondents. Among the 22 respondents who reported their account balances, the mean savings bank balance was $\$ 240$, which is close to the average balance calculated from the annual report of New Jersey's (1881) savings banks. The average reported value of life policies was $\$ 702$, or about seven times the typical industrial life policy and about one-half the amount of the average whole life policy (North 1979). More than $25 \%$ of policies were for $\$ 150$ or less, which is consistent with what is known about the industrial life industry. 


\begin{tabular}{|c|c|c|c|}
\hline \multicolumn{4}{|c|}{ Table 5} \\
\hline \multicolumn{4}{|c|}{ Proportion of households reporting by combination } \\
\hline & Saving bank & Life insurance & $\begin{array}{c}\text { Building } \\
\text { assoc }\end{array}$ \\
\hline Life ins & $\begin{array}{c}0.10 \\
{[0.09]}\end{array}$ & & \\
\hline Building assoc & $\begin{array}{c}0.05 \\
{[0.05]}\end{array}$ & $\begin{array}{c}0.15 \\
{[0.04]}\end{array}$ & \\
\hline $\begin{array}{l}\text { Beneficial } \\
\text { society }\end{array}$ & $\begin{array}{c}0.10 \\
{[0.01]}\end{array}$ & $\begin{array}{c}0.31 \\
{[0.00]}\end{array}$ & $\begin{array}{c}0.17 \\
{[0.00]}\end{array}$ \\
\hline Source: NJBSL & $(1888)$ & & \\
\hline
\end{tabular}

While Table 4 illuminates participation rates in each type of saving organization, Schweiger and McGee (1961) contend that, in the mid-twentieth century at least, savings banks had spillover effects. By encouraging one type of thrift, they encouraged complementary saving behaviors. Table 5 reveals that spillovers were modest in the late nineteenth century. Each cell in Table 5 reports the proportion of households reporting both types of savings implied by the rowcolumn combination, along with the p-value of the Pearson chi-squared statistics testing the null hypothesis of independence. The value in the upper left cell, for instance, implies that $10 \%$ of households reported a savings bank account and a life insurance policy. Five percent report a savings bank account and membership in a building and loan association. Less than 11 percent report participating in any three programs; and just 1.8 percent report participating in all four.

Whereas Schweiger and McGee (1961) attribute mid-century saving synergies to savings banks, in the late nineteenth century fraternal societies created greater synergies. Ten percent of households were simultaneously savings bank and beneficial society members. Nearly a third reported society membership and life insurance; and 17\% reported a combination of society and building and loan memberships. The data on late-nineteenth century household saving demonstrates that households saved, they saved in a variety of ways, and they saved in combinations that suggest some degree of sophistication. Working-class families did 
not rely on stuffing a few dollars under the mattress; many took advantage of the available formal financial institutions.

\section{Institutions, intermediation, and growth}

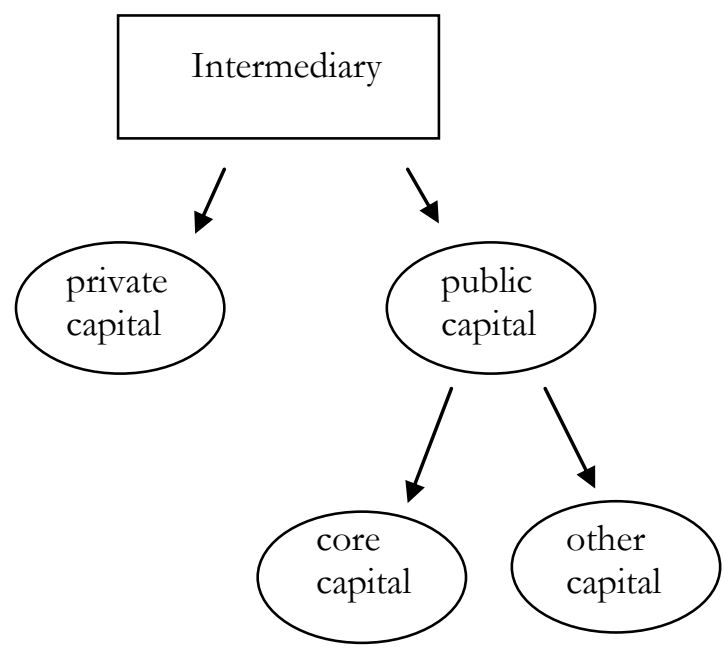

As the subsection of Figure 1 reproduced here reminds us, intermediaries must choose how to allocate the funds savers entrust to them. They might invest in private capital, in public capital, or in some combination of the two. And if they choose to investment in public capital, they must decide between investing in socalled core capital (primarily water, sewer, and other health infrastructure), or other public infrastructure capital (roads, bridges, schools, and so on).

By these criteria beneficial societies and building and loan societies do not qualify as a genuine intermediary. Beneficial societies operated, for philosophical reasons, as close to pay-as-you-go systems as they could. They rarely accumulated more than a minimal reserve fund. Instead, they relied on current premium payments and assessments to meet current claims (New York Insurance Department 1888). Similarly, building and loan associations were highly specialized financial firms that were required to direct nearly all their resources to the residential mortgages of members (Bodfish 1931; Clark and Chase 1925). Building and loans served a vital 
function in a rapidly urbanizing economy (Snowden 2003), but they were not traditional intermediaries in the sense that they held diversified portfolios or mortgage and non-mortgage investments of members and nonmembers alike.

\begin{tabular}{lcccc}
\hline \multicolumn{5}{c}{ Table 6 } \\
\hline \multicolumn{5}{c}{ Portfolio allocations of savings banks and industrial insurance } \\
& $\begin{array}{l}\text { Savings banks } \\
\text { Insurance companies }\end{array}$ & Ins \\
& 1881 & 1888 & 1879 & 1887 \\
Mortgages & $39.5 \%$ & $35.7 \%$ & $40.3 \%$ & $54.7 \%$ \\
Municipal debt & 8.2 & 23.0 & 11.2 & 2.3 \\
State debt & 0.8 & 0.4 & 2.2 & 0.6 \\
Railroad debt & 0.2 & 0.4 & 6.6 & 20.3 \\
Railroad equity & 0.5 & 0.1 & 0.2 & 0.2 \\
US debt & 36.8 & 25.6 & 6.1 & 5.7 \\
Bank deposits & 4.5 & 3.9 & 1.2 & 2.2 \\
Other & 9.5 & 10.9 & 32.2 & 14.0 \\
& \multicolumn{5}{c}{} \\
Sources: NJ Dept of State 1881,$1888 ;$ NJ Secretary of State $1879,1887$. \\
\hline
\end{tabular}

What of savings banks and industrial life insurance companies? Among the financial institutions that served working-class Americans, they qualify as intermediaries. Given the growth and profitability of such investments, savings banks and insurance companies, like building associations, invested between one-third and one-half of their assets in residential mortgages. Unlike building associations, however, savings banks and insurance companies held more diversified portfolios. Several features stand out in Table 6, which reports New Jersey's savings banks' and insurance companies' portfolio allocations. First, both reduced their holdings of US debt during the 1880s. Second, neither initially held a sizeable fraction of their portfolios in railroad securities, but the fraction increased markedly among insurance companies. By decade's end, about one-fifth of insurance investments were in railroads. Third, insurance companies began the decade holding $11.2 \%$ of their assets in municipal debt, but the proportion fell to $2.3 \%$ by the end of the decade. New Jersey's savings banks, on the other hand, increased the fraction of their portfolios in 
municipal debt from $8.2 \%$ to $23.0 \%$. Regulatory restrictions imposed limits on the savings banks' ability to fully diversify; up to 1870 the list of authorized securities included residential mortgages, federal, state, and municipal debt, promissory notes with collateral, commercial bank deposits, and securities issued by railroads chartered by New Jersey (Keyes 1878).

This raises concerns about savings banks as intermediaries. It is possible that in restricting the banks' assets to mortgages and public debt, regulations might have limited any growth-enhancing intermediation. But the 1880s witnessed significantly increased investments in public infrastructure, notably water and sewer facilities. Table 7 reports the mean and median values for the year in which $94 \mathrm{New}$ Jersey municipalities with pre-1900 water-works completed their systems, the amount invested, and the amount financed through long-term debt issues. The mean year in which these communities constructed a water-works was 1883, at an average total cost of $\$ 420,600$, of which $\$ 339,000$ was financed through the issuance of long-term, typically 10- to 30-year, bonds. Cutler and Miller (2006) argue that larger cities operated municipally owned systems, because the capital investments were generally beyond the capacity of private firms, while smaller cities and towns tended to contract with private water companies. New Jersey's municipalities demonstrate the same pattern. The mean municipal system cost five times the mean private system.

In New Jersey, as elsewhere, the ability of municipalities to borrow long term was an important part of the era's push toward clean water, but the evidence concerning the effect of public ownership on water quality relative to private ownership is mixed (Troesken 1999; Troesken and Geddes 2003; Cutler and Miller 2006). In his history of urban infrastructure, Melosi (2000, p. 75) contends that a city's capacity to construct water-works depended on more than the political will to do so; it relied on "the ability of cities to incur debts," and the capacity of cities to tap financial markets "ultimately made the development of public sanitary systems achievable." Absent the ability to place long-term debt, municipalities found that providing infrastructure "strained available [municipal] resources" to such as extent that "developing adequate water and sewer infrastructure seemed an insurmountable task" (Beemer et al 2005, pp. 49-50). 


\begin{tabular}{|c|c|c|c|}
\hline \multicolumn{4}{|c|}{ Table 7} \\
\hline \multicolumn{4}{|c|}{ New Jersey municipal water-works investments } \\
\hline \multicolumn{4}{|c|}{ All new water-works investments } \\
\hline & Year & Cost & Bonded debt \\
\hline Mean & 1883 & $\$ 420,600$ & $\$ 339,880$ \\
\hline Median & 1887 & 72,000 & 48,000 \\
\hline \multicolumn{4}{|c|}{ New private company investments } \\
\hline Mean & 1882 & 120,887 & 39,470 \\
\hline Median & 1888 & 52,000 & 15,000 \\
\hline \multicolumn{4}{|c|}{ New public investments } \\
\hline Mean & 1881 & 616,559 & 536,300 \\
\hline Median & 1883 & 81,471 & 56,750 \\
\hline \multicolumn{4}{|c|}{$\begin{array}{l}\text { Notes: } 59 \text { private and } 35 \text { public investments. The } \\
\text { columns report the mean (median) year in which } \\
\text { New Jersey municipalities began construction of } \\
\text { water-works infrastructure. Columns } 2 \text { and } 3 \text { report } \\
\text { the mean (median) current dollar cost of the } \\
\text { investments and the total value of long-term debt } \\
\text { issued to finance the water-works. } \\
\text { Source: Baker (1897). }\end{array}$} \\
\hline
\end{tabular}

Mutual savings banks' and industrial life insurance companies' willingness to invest in municipal debt allowed New Jersey's cities to surmount the insurmountable. Newark's Comptroller (1886, p.7) argued that the city's long-term bonds were "sought by investors as safe and reliable securities," which enabled Newark and other cities to place them. But municipalities did not rely on sophisticated financial markets to place them; most issues were too small to interest investment banks. Of Newark's 29 separate water bond issues between 1876 and 1897, 12 were less than $\$ 20,000$; seven were between $\$ 20,000$ and $\$ 50,000$; and five more were for less than $\$ 100,000$ (Newark Comptroller 1906, p.10). The city placed its bonds by handing them over to the construction company awarded the contract for the work. In 1891, for example, the East Jersey Water Company won the bid for a new $\$ 4$ million water plant and pumping station and, even for this relatively large bond issue, took the 
city's 4\% bonds at par in payment. The arrangement made "settlement for the new water supply ... very easy for the city," because it imposed the cost of placing the securities on the contracting firm (Newark Comptroller 1892, p.4).

Once they accepted municipal bonds in payment, water-works contractors had to locate investors and most surely turned to New Jersey's and New York's savings banks and industrial insurance companies. Table 8 reports the total value of outstanding water-works debt and all municipal debt for 26 municipalities whose debt was listed in the Commercial and Financial Chronicle. The table also reports the share of all municipal debt held by New Jersey's mutual savings banks and life insurance companies operating in the state. In 1892 about one-third of all municipal debt had been issued to finance water-works. Savings banks and insurance companies combined held $40 \%$ to $45 \%$ of the bonds of the two municipalities with the most expensive water-works - Jersey City and Newark. They also held substantial proportions of the debt of Asbury Park, Bayonne, Rahway and Trenton. For the 26 municipalities combined, savings banks held $10.9 \%$ of their debt; life insurance companies held $26.7 \%$. Two of the principal saving vehicles for New Jersey's working-class households, therefore, intermediated between the state's savers and municipalities constructing the water-works that served saving households themselves. Mutual savings banks and industrial life companies transformed workers' savings into investments in water and sewer systems that, in the long run, helped improve urban workers' health and productivity. 


\section{Table 8}

\begin{tabular}{lcccc}
\hline Proportion of New Jersey municipal debt held by savings banks and life insurance companies \\
Municipality & $\begin{array}{c}\text { Water debt } \\
(\$ 000)\end{array}$ & $\begin{array}{c}\text { Total debt } \\
(\$ 000)\end{array}$ & $\begin{array}{c}\text { Saving banks } \\
(\%)\end{array}$ & $\begin{array}{c}\text { Insurance Co's } \\
\text { Asbury Park }\end{array}$ \\
Bayonne & $\$ 92$ & $\$ 95.3$ & $38.3 \%$ & $0.0 \%$ \\
Camden & 130 & 255.5 & 26.6 & 0.0 \\
Gloucester & 483 & $1,277.8$ & 0.0 & 0.0 \\
Jersey City & 80 & 98 & 0.0 & 0.0 \\
Newark & 5,085 & 9037.8 & 11.4 & 29.3 \\
New Brunswick & 357.2 & 10,759 & 9.9 & 35.3 \\
Orange & 303.5 & $1,602.6$ & 1.1 & 0.8 \\
Rahway & 410 & 693.7 & 5.6 & 26.5 \\
Trenton & 185 & 605 & 1.0 & 7.2 \\
& 210 & $1,085.7$ & 6.9 & 0.0 \\
26 municipalities & 10,934 & $34,723.5$ & 10.9 & 26.7
\end{tabular}

Notes: 26 municipalities with bond prices reported in Commercial and Financial Chronicle (21 May 1892). Column 1 reports the total dollar value of water-works bonds issued by the respective cities outstanding as of May 1892. The second column reports the total value of all municipal debt outstanding. The third and fourth columns report the share of total debt held by savings banks and insurance companies. Columns 3 and 4 use the fraction of total debt because the bank and insurance reports do not systematically differentiate between water-works and other municipal debt in their annual reports.

Sources: NJ Department of State. Annual Statements of Banks and Savings Institutions of the State of New Jersey for the Year 1891. Trenton: John L. Murphy Publishing Co., Printer, 1891.

\section{$5.1 \mathrm{~W}$ ater, water everywhere ...}

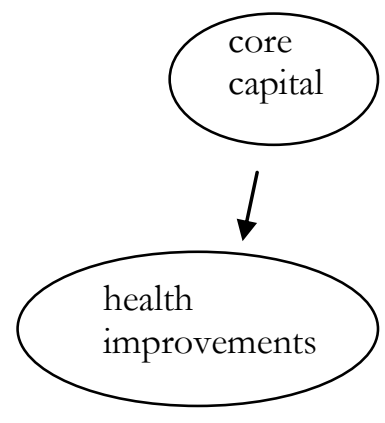


Now that it has been shown that savings banks and industrial life insurance companies invested substantial amounts in public core capital, the subsection of Figure 1 reproduced here reminds us that the issue arises whether such investments paid off in terms of improvements in public health. The evidence is generally consistent with improved health, but supplying homes with municipally supplied water was not enough if the water was impure.

Between 1860 and 1890 the average daily per capita water consumption in Jersey City doubled. Daily per capita consumption was 52 gallons in 1860, which rose to 98 gallons in 1887 (Jersey City Board of Public Works 1887). Table 9 provides statistics of water usage (gals per day per capita) in 1897 and 1915 and taps into system (taps per capita) in 1897 for select New Jersey municipalities. Baker's (1897) estimates for cities with large working-class populations - Camden, Elizabeth, Jersey City, Millville, Newark, and Trenton - are about 100 gallons per day per person. Some of the differences across cities result from the extent to which industrial and commercial enterprises tapped into the various systems (manufacturers in Patterson, for instance, apparently drew water directly from the Passaic River), whether water usage was metered (not yet universal), and how well municipal water agencies maintained chronically leaky mains and pipes (Jersey City Board of Public Works 1887). Daily per capita consumption was higher in 1915 than in 1897 in the handful of cities for which data is available (Mason 1916). The number of taps, or connections, ranged from a low of 0.07 per capita in Millville to 0.29 in Asbury Park. Multiplying taps per capita by four approximates the number of connections per household. As elsewhere in the United States, the provision of water by way of municipal pipes rather than well pumps dramatically increased usage (Melosi 2000). 


\begin{tabular}{lccc}
\hline \multicolumn{4}{c}{ Table 9} \\
\hline \multicolumn{1}{c}{ Water consumption and connections in select New Jersey cities } \\
City & Gals/day/pop & Gals/day/pop & Taps/pop \\
& 1897 & 1915 & 1897.00 \\
Asbury Park & & & \\
Atlantic City & 143 & & 0.29 \\
Bayonne & 344 & 245 & 0.26 \\
Burlington & 68 & & 0.13 \\
Camden & 62 & & 0.25 \\
Elizabeth & 206 & 125 & 0.16 \\
Gloucester City & 106 & 164 & 0.14 \\
Jersey City & 76 & & 0.15 \\
Millville & 118 & 156 & 0.13 \\
New & 100 & & 0.07 \\
Brunswick & 86 & & 0.15 \\
Newark & & & \\
Paterson & 122 & 102 & 0.10 \\
Rahway & 13 & & 0.08 \\
Somerville & 97 & & 0.08 \\
Trenton & 117 & & 0.09 \\
& 96 & & \\
Sources: Baker (1897); Mason (1916). & & \\
\hline
\end{tabular}

Cutler and Miller (2006) argue that the political and economic impetus behind the late nineteenth-century push toward the provision of abundant, cheap and clean water lies less in the recognition of the connection between clean water and waterborne diseases, such as cholera, dysentery, and typhoid, than in the ability of cities to tap into expanding and modernizing financial markets. People had long recognized the correlation between impure water and chronic urban diarrheal diseases, as well as the occasional acute outbreak, even if they did not understand the causal mechanism. Late nineteenth-century observers were especially concerned with typhoid, claiming that for every typhoid death avoided three additional premature deaths were avoided. The effect is attributed not the elimination of typhoid per se, which had a relatively low mortality rate among those who contracted the disease, but to the fact that typhoid compromised the immune system. Prior typhoid 
infection increased the probability of early death from other infections, such as tuberculosis, pneumonia, and influenza (Ferrie and Troesken 2008).

\begin{tabular}{|c|c|c|c|}
\hline \multicolumn{4}{|c|}{ Table 10} \\
\hline \multicolumn{4}{|c|}{ Typhoid death rates per 100,000} \\
\hline Year & Newark & Jersey City & Paterson \\
\hline 1880 & 53.1 & 25.7 & 39.2 \\
\hline 1881 & 36.4 & 63.2 & 53.9 \\
\hline 1882 & 67 & 120.8 & 86.7 \\
\hline 1883 & 59.6 & 48.7 & 52.3 \\
\hline 1884 & 56.5 & 84.3 & 54.9 \\
\hline 1885 & 59.2 & 70.5 & 60.3 \\
\hline 1886 & 52.1 & 60.2 & 31.1 \\
\hline 1887 & 50 & 53.9 & 28.5 \\
\hline 1888 & 44 & 73.8 & 28.8 \\
\hline 1889 & 73.9 & 83.1 & 34.4 \\
\hline 1890 & 106.7 & 97.5 & 5.1 \\
\hline 1891 & 71.2 & 99.8 & 21 \\
\hline 1892 & 78.6 & 71.6 & 17.9 \\
\hline 1893 & 31.3 & 65.9 & 40.5 \\
\hline 1894 & 20.7 & 53.2 & 7.9 \\
\hline 1895 & 20.1 & 94.2 & 26.2 \\
\hline 1896 & 27.7 & 83.6 & 45.5 \\
\hline 1897 & 19.4 & 19.6 & 50.5 \\
\hline 1898 & 13.3 & 40 & 38.1 \\
\hline 1899 & 35.5 & 19.3 & 57.6 \\
\hline 1900 & 10.2 & 21.3 & 27.6 \\
\hline Passaic River & 62.2 & 73.6 & 39.5 \\
\hline Pequanock River & 22.2 & 25.1 & -- \\
\hline $\begin{array}{l}\text { Source: NJ Board } \\
(1899)\end{array}$ & Health (18 & ); Newark D & ent of Health \\
\hline
\end{tabular}

Typhoid death rates for three New Jersey cities in the Passaic River watershed reported in Table 10 reveal that the installation of water and sewer systems alone did not resolve the typhoid problem if the water moving through the system was drawn from rivers contaminated by upstream pollutants. Newark and Jersey City drew their water from the Passaic River, which was known as early as 1887 to be heavily polluted with sewage and industrial wastes dumped by the 
upstream cities of Paterson and Passaic (Newark Board of Health 1887). ${ }^{4}$ Until 1892 typhoid death rates in Newark remained high and on par with other cities, like Pittsburgh, that relied on adjacent rivers for city water (Beach et al 2016). After 1892 Newark drew most of its water from the less polluted Pequanock River with additional supplies from deep wells at Belleville (Newark Department of Public Health 1899).

Following the change in the source the city's water financed through direct placement of its debt, typhoid death rates fell immediately in Newark. Jersey City switched to Pequanock-supplied water only in 1897, after which its typhoid death rates also fell. By century's end, typhoid mortality rates in Newark and Jersey City fell below the upstream Patterson rate of 35 to 40 per 100,000. Additional declines in typhoid rates awaited the adoption of water filtration and chlorination, as well as the elimination of urban privy vaults and cesspools, which remained "fertile sources of disease" because they contaminated surrounding soil and leached into private wells (Billings 1897, p.134). Despite the public provision of water, Newark's Board of Health (1887) reported 1,129 private wells still in use, the occasional contamination of which may account for periodic spikes in typhoid mortality.

\subsection{Public investment and productivity}

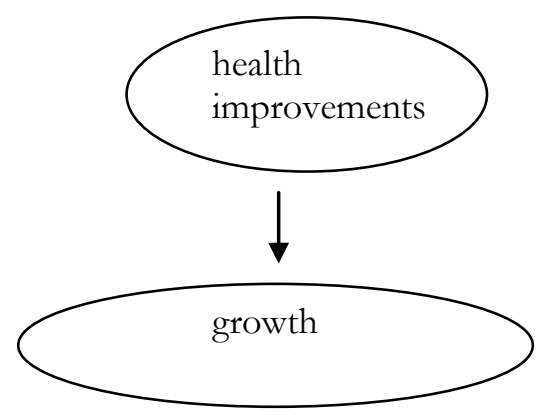

4 Typhoid rates in Camden (downstream) and Trenton (upstream) each of which drew its water from the Delaware River reveal similar differentials. The average typhoid death rate in Camden between 1880 and 1900 was 76.8 compared to Trenton's 32.5 (NJ Board of Health 1880-1900). 
Did savings banks' and life insurance companies' willingness to invest in municipal bonds that financed water and sewer investments positively influence economic growth? Unfortunately, the available evidence from New Jersey does not provide a direct test, but there is evidence from other places consistent with the hypothesis. Beginning with Aschauer (1989) several articles have investigated whether public investments promote aggregate economic or total factor productivity (TFP) growth. Aschauer (1989) includes public capital in a standard Solow growth model, first, to provide a theoretical foundation for why water and sewer services, roads and other public capital might influence growth, and, second, to generate econometric estimates of any effect. For the postwar US, he finds that a $1 \%$ increase in the stock of public capital is associated with a $0.39 \%$ increase in total factor productivity growth. The effect of "core" infrastructure, defined as roads, and watersewer investments, is such that a $1 \%$ increase in core capital is associated with a $0.24 \%$ increase in TFP growth.

Aschauer's (2000) subsequent study takes into account Hulten's (1996) and Barro's (1991) criticisms and still finds that the net effect of debt-financed public infrastructure is positive, significant, and meaningful. His estimates also imply that the optimal public capital-output ratio is about 0.5 , but that the mean ratio in 46 lowand middle-income countries is 1.32. It is possible that many modern economies, even low-income ones, have overinvested in public capital. This possibility hardly seems a concern for late nineteenth-century Newark or Jersey City. Overflowing urban privies and muddy streets were common features of most contemporary urban places, and "manifest physical representations of the city's problems" (Cain 1972, p.371). Citizens agreed to tax assessments to finance sanitary conditions, which benefitted all the city's residents but may have benefitted the working poor relatively more (Troesken 2001).

Aschauer's findings have not gone unchallenged, of course, but the weight of the evidence suggests that public capital, even debt-financed public capital, increases private sector growth. Barro (1991) finds it for a sample of 76 countries. Easterly and Rebelo (1993) find it for 100 countries. Nourzad and Vrieze (1995) find the effects in OECD countries. Harchaoui et al (2004) find it in post-1960 Canada. And a metaanalysis of 68 studies (578 separate estimates) suggests a short-run output elasticity to 
central-government public capital of 0.08 and a long-run elasticity of 0.12 . The elasticities of core capital by local and regional governments are nearly double these values (Born and Ligthart 2013). Alternative approaches also tend to support the productivity enhancing effects of core public capital. Invoking the cost-dual, Morrison and Schwartz (1996) estimate cost functions for manufacturing firms and find substantial cost savings attributable to public investment.

A growing literature in economic history makes use of newly constructed longitudinal data sets to address the connection between disease eradication efforts and long-run growth. Bleakley (2007), for example, finds that the Rockefeller Foundation's hookworm eradication program in the southern US increased school enrollments, literacy and, importantly, the returns to education three decades later. Childhood hookworm infection reduced later-life wages (and by implication productivity) by approximately 40\%. Similar effects on school enrollments and laterlife health resulted from malaria eradication efforts in the South (Bleakley 2003).

Beach et al (2014) provide the first analysis of the long-run effects of typhoid exposure in the early twentieth century. They estimate that eliminating early-life exposure to typhoid increased educational attainment and later-life earnings by between 1\% and 9\%. Their results are consistent with Case and Paxson's (2009) findings that early exposure to typhoid reduced cognitive function among surviving 50 to 90 year-olds and Costa's (2000) finding that early exposure negatively affects late-life cardiac and respiratory function. By reducing the fraction of impaired individuals, whether cognitively or physically, by early-life exposure to typhoid and other waterborne diseases, the construction and modernization of New Jersey's late nineteenth-century waterworks surely contributed to long-term human capital development and, thereby, to economic development.

Savings banks and industrial life insurance companies played no small part by making markets in the municipal debt that financed the urban waterworks with documented effects on long-term productivity. Intermediaries also invested in municipal bonds that financed the construction of schools, urban street lights, roads and bridges, and a host of other public investments that complemented private capital. 


\section{Concluding comments}

Saving is essential to the health of economies and households, yet relatively little historical scholarship investigates saving behaviors among the urban working class in the nineteenth century. This paper uses five surveys of industrial workers in 1880s New Jersey, an analysis of which reveals relatively sophisticated saving practices consistent with life-cycle and precautionary approaches. Estimated saving rates are consistent with three features evident in modern developing economies: some households saved little or nothing, consistent with consumer impatience; regular dissaving points to prior saving in the face of the era's uncertain incomes; and saving rates rose with income (Deaton 1991).

Moreover, households took advantage of nearly every type of saving institution. Two of the more common outlets for household saving - mutual savings banks and industrial life insurance companies - then allocated mobilized savings into highly productive sectors, including public infrastructure. More than one-third of the combined assets of New Jersey's mutual savings banks and industrial life companies were invested in municipal debt, much of which was issued to finance public infrastructure. Investments in core public capital, notably public waterworks and sewer systems, had positive effects on health. As the state's municipalities constructed new or upgraded existing waterworks between 1870 and 1890, the incidence of typhoid declined markedly. Historical health economists document the longer term negative health and productivity consequences of typhoid and other diseases. A diminution in the incidence of such infections likely led to increases in labor productivity and, ultimately, on long-run growth. It might be fairly concluded, then, that New Jersey's working-class savers exhibited what Modigliani (1986, p.297) and Wadhwani (2002) labeled the civic virtue of saving. Working-class savings, mediated through the era's available financial institutions, redounded to their own benefit. 


\section{References}

Adams, Dale W. and Robert C. Vogel. 1986. "Rural financial market in low-income countries: recent controversies and lessons." World Development 14(4): 477487.

Alter, George, Claudia Goldin, and Elyce Rotella. 1994. "The savings of ordinary Americans: The Philadelphia Saving Fund Society in the mid-nineteenth century." Journal of Economic History 54(4): 735-767.

Aschauer, David A. 1989. "Is public expenditure productive?" Journal of Monetary Economics 23(2): 177-200.

Aschauer, David A. 2000. "Public capital and economic growth: issues of quantity, finance, and efficiency." Economic Development and Cultural Change 48(2): 391406.

Atack, Jeremy, Matthew S. Jaremski, and Peter L. Roussesau. 2015. "Did railroads make antebellum US banks more sound?" In Enterprising America: Businesses, Banks, and Credit Markets in Historical Perspectives, pp. 149-178. Edited by William J. Collins and Robert A. Margo. Chicago: University of Chicago Press.

Averett, Susan, Howard Bodenhorn, and Justus Staisiunas. 2005. "Unemployment risk and compensating differentials in late-nineteenth-century New Jersey manufacturing." Economic Inquiry 43(4): 734-749.

Baker, M. N. 1897. The Manual of American Water-Works 1897. Fourth Issue. New York: Engineering News Publishing Co.

Barro, Robert J. 1991. "A cross-country study of growth, saving, and government." In National Saving and Economic Performance, pp. 271-304. Edited by B. Douglas Bernheim and John B. Shoven. Chicago: University of Chicago Press.

Beach, Brian, Joseph Ferrie, Martin Saavedra, and Werner Troesken. 2016. "Typhoid fever, water quality, and human capital formation." Journal of Economic History $76(1): 41-75$.

Beemer, Jeffrey K., Douglas Anderton, and Susan Hautaniemi Leonard. 2005. "Sewers in the city: a case study of individual-level mortality and public health initiatives in Northampton, Massachusetts at the turn of the century." Journal of the History of Medicine and Allied Sciences 60(1): 42-72. 
Beito, David T. 2000. From Mutual Aid to Welfare State: Fraternal Societies and Social Services, 1890-1967.” Chapel Hill: University of North Carolina Press.

Bencivenga, Valerie and Bruce D. Smith. 1991. "Financial intermediation and endogenous growth." Review of Economic Studies 58(x): 195-209.

Berger, Allen N., Asli Demirgüc-Kunt, Ross Levine, and Joseph G. Haubrich. "Bank concentration and competition: an evolution in the making." Journal of Money, Credit, and Banking 36(3): 433-451.

Bernheim, .

Billings, John S. 1897. "A statistical inquiry into the relation between contaminated drinking water and typhoid fever." Albany Medical Annals 18(3): 127-134.

Bleakley, Hoyt. 2003. "Disease and development: evidence from the American South." Journal of the European Economic Association 1(2): 376-386.

Bleakley, Hoyt. 2007. "Disease and development: evidence from hookworm eradication in the American south." Quarterly Journal of Economics 122(1): 73117.

Bodenhorn, Howard. 2000. A History of Banking in Antebellum America: Banks and ... New York: Cambridge University Press.

Bodenhorn, Howard. 2016. "Two centuries of finance and growth in the United States, 1790-1980.” NBER working paper no.

Bodfish, H. Morton. 1931. History of Building and Loan in the United States. Chicago: United States Building and Loan League.

Born, Pedro R. D. and Jenny E. Ligthart. 2013. "What have we learned from three decades of research on the productivity of public capital?" Journal of Economic Surveys 28(5): 889-916.

Brady, Dorothy S. and Rose D. Friedman. 1947. "Savings and the income distribution." In Studies in Income and Wealth Volume Ten, pp. 247-265. Conference on Research in Income and Wealth. New York: National Bureau of Economic Research.

Browning, Martin and Annamaria Lusardi. 1996. "Household saving: micro theories and micro facts." Journal of Economic Literature 34(4): 1797-1855.

Cain, Louis P. 1972. "Raising and watering a city: Ellis Sylvester Chesbrough and Chicago's first sanitation system.” Technology and Culture 13(3): 353-372. 
Carter, Susan et al. 2006. Historical Statistics of the United States, Millennial Edition. New York: Cambridge University Press.

Case, Anne and Christina Paxson. 2009. "Early life health and cognitive function in old age." American Economic Review 99(2): 104-109.

Chalupníček, Pavel and Lukáš Dvorák. 2009. "Health insurance before the welfare state: the destruction of self-help by state intervention." Independent Review 13(3): 367-387.

Clark, Horace F. and Frank A. Chase. 1925. Elements of the Modern Building and Loan Associations. New York: Macmillan Company.

Commerical and Financial Chronicle. 1892. State and City Supplement, May 21, 1892. New York: B. Dana \& Co.

Costa, Dora. 2000. "Understanding the twentieth century decline in chronic conditions among older men." Demography 37(1): 53-72.

Cutler, David and Grant Miller. 2006. "Water, water everywhere: municipal finance and water supply in American cities." In Corruption and Reform: Lessons from America's Economic History, 153-83. Edited by Edward L. Glaeser and Claudia Goldin. Chicago: University of Chicago Press.

Easterly, William and Sergio Rebelo. 1993. "Fiscal policy and economic growth." Journal of Monetary Economics 32(3): 417-458.

Emery, George and J. C. Herbert Emery. 1999. A Young Man's Benefit: The Independent Order of Odd Fellows and Sickness Insurance in the United States and Canada, 1860 1929. Montreal: McGill-Queen's University Press.

Ferrie, Joseph P. and Werner Troesken. 2008. "Water and Chicago's mortality transition, 1850-1925." Explorations in Economic History 45(1): 1-16.

Field, Alexander J. 2011. A Great Leap Forward: 1930s Depression and U.S. Economic Growth. New Haven: Yale University Press.

Fishlow, Albert. 1965. American Railroads and the Transformation of the Ante-bellum Economy. Harvard Economic Studies Vol. 127. Cambridge: Harvard University Press.

Fogel, Robert W. 1962. "A quantitative approach to the study of railroads in American economic growth: a report of some preliminary findings." Journal of Economic History 22(2): 163-197. 
Greenwood, Jeremy and Boyan Jovanovic. 1990. "Financial development, growth, and the distribution of income." Journal of Political Economy 98(x): 1076-1108.

Greenwood, Jeremy and Bruce D. Smith. 1997. "Financial markets in development, and the development of financial markets." Journal of Economic Dynamics and Control 21(x): 145-181.

Harchaoui, Tarek M., Faouzi Tarkhani, and Paul Warren. 2004. "Public infrastructure in Canada, 1961-2002." Canadian Public Policy 30(3): 303-318.

Hicks, John. 1969. A Theory of Economic History. Oxford: Oxford University Press.

Hoffman, Frederick L. 1905. "Industrial insurance." Annals of the American Academy of Political and Social Science 26: 103-119.

Jersey City (New Jersey) Board of Public Works. 1887. Report of the Chief Engineer for the Year Ending Dec. 31, 1880. Jersey City: Albert Datz, Stationer and Printer.

Keyes, Emerson W. 1878. A History of Savings Banks in the United States from Their Inception in 1816 Down to 1877. Vol. II. New York: Bradford Rhodes.

King, Robert G. and Ross Levine. 1993. "Finance and growth: Schumpeter might be right." Quarterly Journal of Economics 108(3): 717-737.

Kotlikoff, Laurence. 1989. What Determines Savings? Cambridge: MIT Press.

Lamoreaux, Naomi R. 1994. Insider Lending: Banks, Personal Connections, and Economic Development in Industrial New England. New York: Cambridge University Press.

Levine. Ross. 1997. "Financial development and economic growth: views and agenda." Journal of Economic Literature 35(2): 688-726.

Levine, Ross. 1998. "The legal environment, banks, and long-run economic growth." Journal of Money, Credit, and Banking 30(3): 596-613.

Mason, William P. 1916. Water-Supply. $4^{\text {th }}$ ed. New York: John Wiley \& Sons, Inc.

Massachusetts. Insurance Commissioner. 1880-1882. Annual Report of the Insurance Commissioner of the Commonwealth of Massachusetts. Part II. Life, Casualty, and Accident Insurance. Boston. Rand, Abery \& Co., Printers to the Commonwealth.

Melosi, Martn V. 2000. The Sanitary City: Urban Infrastructure in America from Colonial Times to the Present. Baltimore: Johns Hopkins University Press.

Merton, Robert C. and Zvi Bodie. 1995. The Global Financial System: A Functional Perspective. Cambridge: Harvard Business School Press. 
Meyer, B. H. 1901a. "Fraternal beneficiary societies in the United States." American Journal of Sociology 6(5): 646-661.

Meyer, B. H. 1901b. "Fraternal insurance in the United States." Annals of the American Academy of Political and Social Science 17: 80-106.

Morrison, Catherine J. and Amy Ellen Schwartz. 1996. "State infrastructure and productive performance." American Economic Review 86(5): 1095-1111.

Murray, John E. 2007. Origins of American Health Insurance: A History of Industrial Sickness Societies. New Haven: Yale University Press.

National Fraternal Congress. 1897. "Report of the committee on statistics and good of the orders." Proceedings of the Eleventh Annual Session of the National Fraternal Congress. Buffalo, NY: Baker, Jones \& Company.

New Jersey Board of Health. 1880 - 1900. Annual Report of the Board of the State of New Jersey. Trenton: publisher varies.

New Jersey. Department of State. 1882 - 1889. Annual Statements of the Banks and Savings Institutions of the State of New Jersey. Trenton: John L. Murphy Publishing Company, State Printers.

New Jersey. Secretary of State. 1876 - 1888. Report of the Secretary of State as Commissioner of Insurance. Part II. Life Insurance. Trenton: John F. Babcock, Book Printer.

New Jersey. Sewerage Commission. 1907. Report of the State Sewwerage Commission to the Legislature of 1907. Trenton: MacCrellish \& Quigley, State Printers.

New York. Insurance Department. 1879-1888. Annual Report of the Superintendent of the Insurance Department, State of New York. Part II. Albany: Weed, Parsons \& Company.

Newark (New Jersey) Board of Health. 1887. Annual Report.

Newark (New Jersey) Comptroller. 1886. Annual Reports of the Comptroller, Commissioners of the Sinking Fund, and Treasurer of the City of Newark, N.J. for the Year 1885. Newark: Advertiser Steam Printing House.

Newark (New Jersey) Comptroller. 1892. Annual Reports of the Comptroller, Commissioners of the Sinking Fund, and Treasurer of the City of Newark, N.J. for the Year 1891. Newark: W. H. Shurts. 
Newark (New Jersey) Comptroller. 1906. Annual Reports of the Comptroller, Commissioners of the Sinking Fund, and Treasurer of the City of Newark, N.J. for the Year 1905. Newark: Baker Printing Co.

Newark (New Jersey) Department of Public Health. 1899. Annual Report.

North, Douglass. 1979. "Capital accumulation in life insurance between the Civil War and the investigation of 1905." In Men in Business: Essays on the Historical Role of the Entrepreneur, pp. 238-253. Edited by William Miller. Westport, Conn.: Greenwood Press.

Nourzad, Farrokh and Martin D. Vrieze. 1995. "Public capital formation and productivity growth: some international evidence." Journal of Productivity Analysis 6(4): 283-295.

O'Grada, Cormac and Eugene N. White. 2003. "The panics of 1854 and 1857: a view from the emigrant industrial savings bank." Journal of Economic History 63(1): 213-240.

Olmstead, Alan L. 1976. New York City Mutual Savings Banks, 1819-1861. Chapel Hill: University of North Carolina Press.

Payne, Peter L. and Lance E. Davis. 1956. The Savings Bank of Baltimore, 1818-1866: A Historical and Analytical Study. Baltimore: Johns Hopkins University Press.

Pennsylvania. Insurance Commissioner. 1882-1883. Annual Report of the Insurance Commissioner of the State of Pennsylvania. Part II. Life and Accident Insurance. Harrisburg: Lanes S. Hart, State Printer.

Ramírez, Carlos D. 2009. “Bank fragility, 'money under the mattress,' and long-run growth: US evidence from the 'perfect' panic of 1893." Journal of Banking and Finance 33(x): 2185-2198.

Ransom, Roger L. and Richard Sutch. 1995. "The impact of aging on the employment of men in American working-class communities at the end of the nineteenth century." In Aging in the Past: Demography, Society, and Old Age, pp. 303-327. Edited by David I. Kertzer and Peter Laslett. Berkeley: University of California Press.

Rhode, Paul W. 2002. “Gallman's annual output series for the United States, 18341909.” National Bureau of Economic Research working paper 8860. 
Rockman, Seth. 2009. Scraping By: Wage Labor, Slavery, and Survival in Early Baltimore. Baltimore: Johns Hopkins University Press.

Rockoff, Hugh. 1975. "Varieties of banking and regional economic development in the United States, 1840-1860.” Journal of Economic History 35(1): 160-181.

Rousseau, Peter L. and Richard Sylla. 2005. "Emerging financial markets and early US growth." Explorations in Economic History 42(1): 1-26.

Schoenfeld, Margaret H. 1925. "Trend of wage earners' savings in Philadelphia." Annals of the American Academy of Political and Social Science 121: 1-65.

Schweiger, Irving and John S. McGee. 1961. Chicago Banking: The Structure and Performance of Banks and Related Financial Institutions in Chicago and Other Areas. Chicago: University of Chicago Graduate School of Business.

Snowden, Kenneth A. 2003. "The transition from building and loan to savings and loan, 1890-1940.” In Finance, Intermediaries, and Economic Development, pp. 157208. Edited by Stanley L. Engerman, Philip T. Hoffman, Jean-Laurent Rosenthal, and Kenneth L. Sokoloff. New York: Cambridge University Press.

Sutch, Richard. 2011.

Troesken, Werner. 1999. "Typhoid rates and the public acquisition of private waterworks, 1880-1920." Journal of Economic History 59(4): 927-948.

Troesken, Werner. 2001. "Race, disease, and the provision of water in American cities, 1889-1921.” Journal of Economic History 61(3): 750-776.

Troesken, Werner and Rick Geddes. 2003. "Municipalizing American waterworks, 1897-1915." Journal of Law, Economics, and Organization 19(2): 373-400.

United States Census Bureau. 2017. Historical Census of Housing Tables. Available at https://www.census.gov/hhes/www/housing/census/historic/owner.html.

Waddhwani, Rohit D. 2002. Citizen Savers: The Family Economy, Financial Institutions, and Social Policy in the Northeastern U.S. from the Market Revolution to the Great Depression. Ph.D. dissertation: University of Pennsylvania.

Wilhelm, William J., Jr. 2001. "The internet and financial markets.” Said Business School working paper, Oxford University. 
Samuel H. Williamson, "Seven Ways to Compute the Relative Value of a U.S. Dollar Amount, 1774 to present," MeasuringWorth, 2017. 